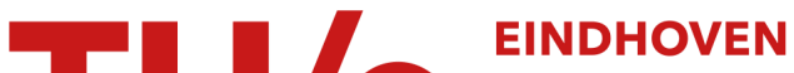 \\ UNIVERSITY OF \\ TECHNOLOGY
}

\section{Mass transport in a hydrogen gas diffusion electrode}

\author{
Citation for published version (APA): \\ Vermeijlen, J. J. T. T., \& Janssen, L. J. J. (1993). Mass transport in a hydrogen gas diffusion electrode. Journal \\ of Applied Electrochemistry, 23(12), 1237-1243. https://doi.org/10.1007/BF00234806
}

DOI:

10.1007/BF00234806

Document status and date:

Published: 01/01/1993

\section{Document Version:}

Publisher's PDF, also known as Version of Record (includes final page, issue and volume numbers)

\section{Please check the document version of this publication:}

- A submitted manuscript is the version of the article upon submission and before peer-review. There can be important differences between the submitted version and the official published version of record. People interested in the research are advised to contact the author for the final version of the publication, or visit the $\mathrm{DOI}$ to the publisher's website.

- The final author version and the galley proof are versions of the publication after peer review.

- The final published version features the final layout of the paper including the volume, issue and page numbers.

Link to publication

\section{General rights}

Copyright and moral rights for the publications made accessible in the public portal are retained by the authors and/or other copyright owners and it is a condition of accessing publications that users recognise and abide by the legal requirements associated with these rights.

- Users may download and print one copy of any publication from the public portal for the purpose of private study or research.

- You may not further distribute the material or use it for any profit-making activity or commercial gain

- You may freely distribute the URL identifying the publication in the public portal.

If the publication is distributed under the terms of Article 25fa of the Dutch Copyright Act, indicated by the "Taverne" license above, please follow below link for the End User Agreement:

www.tue.nl/taverne

Take down policy

If you believe that this document breaches copyright please contact us at:

openaccess@tue.nl

providing details and we will investigate your claim. 


\title{
Mass transport in a hydrogen gas diffusion electrode
}

\author{
J. J. T. T. VERMEIJLEN, L. J. J. JANSSEN \\ Faculty of Chemical Engineering, Laboratory of Instrumental Analysis, Eindhoven University of Technology, \\ P.O. Box 513, $5600 \mathrm{MB}$ Eindhoven, The Netherlands
}

Received 18 October 1992; revised 17 May 1993

Experimental data are presented concerning the diffusion-limited current density for hydrogen oxidation in a gas diffusion electrode (GDE) under various conditions. These current densities were obtained using mixtures of hydrogen and inert gases. To elucidate the dependence of the overall mass transport coefficient on the gas phase diffusion coefficient and the liquid phase diffusion coefficient of the hydrogen, a simplified model was derived to describe the transport of hydrogen in a GDE based on literature models. The GDE consists of a hydrophobic and a hydrophilic layer, namely a porous backing and a reaction layer. The model involves gas diffusion through the porous backing of the GDE combined with gas diffusion, gas dissolution and reaction in the reaction layer of the electrode. It was found that the transport rate of hydrogen under the experimental circumstances is determined by hydrogen gas diffusion in the pores of the porous backing, as well as in the macropores of the reaction layer. Diffusion of dissolved hydrogen in the micropores of the reaction layer, through the liquid, is shown to be of little significance.

\section{Notation}

$A_{\mathrm{gd}}$ geometric electrode surface area $\left(\mathrm{m}^{2}\right)$

$c_{\text {in }}$ concentration of reactive component at the inlet of the gas compartment $\left(\mathrm{mol} \mathrm{m}^{-3}\right)$

$c_{\text {out }}$ concentration of reactive component in and at the outlet of the gas compartment $\left(\mathrm{mol} \mathrm{m}^{-3}\right)$

$c_{\mathrm{SA}}$ concentration of sulphuric acid in the solution compartment $\left(\mathrm{mol} \mathrm{m}^{-3}\right)$

$c$ concentration of reactive component in a gas diffusion electrode $\left(\mathrm{mol} \mathrm{m}^{-3}\right)$

$D_{i, j}(T)$ interdiffusion coefficient for gas $i$ in gas $j$ at a temperature $T\left(\mathrm{~m}^{2} \mathrm{~s}^{-1}\right)$

$D_{1}$ diffusion coefficient for electroactive species in solution $\left(\mathrm{m}^{2} \mathrm{~s}^{-1}\right)$

$E$ electrode potential (V)

$E_{\mathrm{e}} \quad$ equilibrium electrode potential (V)

$E_{\mathrm{t}} \quad$ upper limit electrode potential (V)

$F_{\mathrm{v}, \text { in }}$ volumetric flow rate at the inlet of the gas compartment $\left(\mathrm{m}^{3} \mathrm{~s}^{-1}\right)$

$F_{\mathrm{v}, \mathrm{N}}$ volumetric flow rate of nitrogen at the inlet of the gas compartment $\left(\mathrm{m}^{-3} \mathrm{~s}^{-1}\right)$

$F_{\mathrm{m} \text {, in }}$ mass flow rate at the inlet of the gas compartment $\left(\mathrm{kg} \mathrm{s}^{-1}\right)$

$\mathscr{F} \quad$ Faraday constant $\left(\right.$ A s mol $\left.{ }^{-1}\right)$

$H$ Henry's constant defined by Equation $9(-)$

$i_{\text {gd,1 }}$ diffusion limited current density for gas diffusion electrode $\left(\mathrm{A} \mathrm{m}^{-2}\right)$

$i_{\mathrm{gd}, 1, \text { calc }}$ calculated diffusion limited current density for gas diffusion electrode $\left(\mathrm{A} \mathrm{m}^{-2}\right)$

$i_{3} \quad$ local current density for hydrogen oxidation reaction in a micropore of the gas diffusion electrode $\left(\mathrm{A} \mathrm{m}^{-2}\right)$

$I_{\mathrm{hp}}$ current for hydrogen production (A) $k_{2} \quad$ effective rate constant of gas transport into micropores of gas diffusion electrode per unit of macropore surface $\left(\mathrm{m} \mathrm{s}^{-1}\right)$

$k_{3}$ electrochemical rate constant of the hydrogen oxidation reaction $\left(\mathrm{m} \mathrm{s}^{-1}\right)$

$k_{\mathrm{s}}$ mass transport coefficient $\left(\mathrm{m} \mathrm{s}^{-1}\right)$

$L$ effective length of a pore (m)

$M$ effective pore concentration per unit of geometric electrode surface area $\left(\mathrm{m}^{-2}\right)$

$N$ hydrogen flux $\left(\mathrm{mol} \mathrm{s}^{-1}\right)$

$n$ number of electrons involved in the electrode reaction

$r$ effective pore radius (m)

$S$ effective cross-sectional pore area, $\pi r^{2}\left(\mathrm{~m}^{2}\right)$

$T$ temperature $(\mathrm{K})$

$V_{\mathrm{m}}$ molar volume of gas $\left(\mathrm{m}^{3} \mathrm{~mol}^{-1}\right)$

$\alpha$ Bunsen coefficient $(-)$

$\eta \quad$ overpotential (V)

Subscripts

the gas-filled macropores of the porous backing

2 the gas-filled macropores of the reaction layer

3 the solution-filled micropores of the reaction layer

1,2 at the mouth of the macropores of the reaction layer at the interface of macropores of the porous backing and the macropores of the reaction layer

2,3 at the mouth of a micropore in the reaction layer at the interface of macro and micropore in the reaction layer

$\mathrm{G}$ gas phase

L liquid phase 


\section{Introduction}

Gas diffusion electrodes (GDEs) have been developed and optimized for use in fuel cells for direct energy conversion. In recent years the applicability of the GDE in other fields of applied electrochemistry has received increasing attention. In particular, the hydrogen GDE, used as anode in metal deposition processes, has been the subject of several investigations. In this paper results are presented for commercially available GDEs developed for phosphoric acid fuel cells at high temperatures, viz $200^{\circ} \mathrm{C}$, applied in dilute sulphuric acid solutions at low temperatures, from 25 to $70^{\circ} \mathrm{C}$.

To describe the behaviour of gas diffusion electrodes, many models have been proposed [1-6]. Some models include possible gas-phase transport limitations, whereas others neglect the influence of these gas-phase phenomena, since the diffusion coefficient of the reactant gas dissolved in the liquid phase is small compared to the diffusion coefficient of the reactant gas in the gas phase.

A GDE, as used in this paper, consists of two layers. The gas side layer is a porous substrate acting as electrode support and current collector and allows the gas to reach the catalysed reaction layer. The liquid side layer is the catalysed reaction layer and consists of a network of gas-filled macropores and liquid-filled micropores.

Hydrogen is transported through the pores of the porous backing into the macropores of the reaction layer. Subsequently it dissolves in the solution of the micropores of the reaction layer. It then diffuses towards the reaction sites where it is oxidized.
To investigate the rate determining step for hydrogen transport in a GDE under diffusion limited conditions, a mixture of hydrogen gas and an inert gas was supplied to the gas diffusion electrode. The limiting current density for hydrogen oxidation was determined as a function of a number of parameters, e.g. composition of solution, type of inert gas, temperature, gas pressure and liquid pressure.

In a previous paper [7] the overall mass transport coefficient for a GDE under diffusion-limited conditions was determined where the concentration of reactant gas in the gas compartment adjacent to the porous substrate of the GDE was calculated with a CSTR reactor model for the gas compartment. In this work experimental results are presented to elucidate the diffusion rate-determining step.

\section{Experimental details}

The experimental set-up is shown in Fig. 1. Some adaptions to the experimental set-up as described in [7] were made to allow the gas to be saturated with water vapour at the cell operating temperature and to vary the gas and liquid pressure.

The experimental cell has been described previously [7]. It was fitted with Fuel Cell Grade Electrodes on Toray Paper purchased from E-TEK, USA. These gas-diffusion electrodes were loaded with $0.50 \mathrm{mg}$ $\mathrm{cm}^{-2}$ platinum. The active (hydrophilic) layer has a thickness of approximately $0.1 \mathrm{~mm}$, whereas the total electrode thickness measures approximately $0.55 \mathrm{~mm}$. A geometric electrode surface area of $20 \times 20 \mathrm{~mm}^{2}$ was exposed to gas and solution.

The solutions used were 0.5 to $9 \mathrm{M} \mathrm{H}_{2} \mathrm{SO}_{4}$ prepared

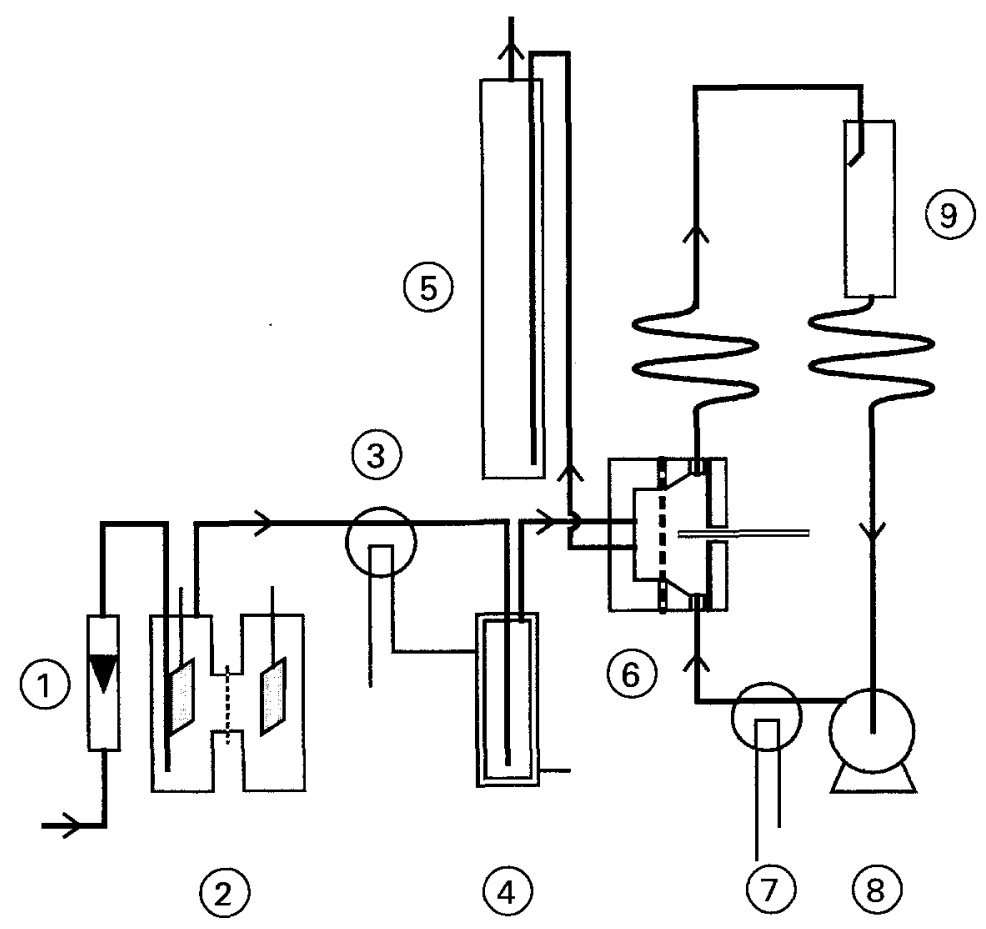

Fig. 1. Schematic illustration of the experimental setup. (1) Flowmeter, (2) hydrogen generation cell, (3) heat exchanger for gas, (4) water saturation vessel for gas, (5) water column for gas overpressure, (6) test cell, (7) heat exchanger for solution, (8) solution pump and (9) solution storage vessel. 
from sulphuric acid p.a. (Merck) and deionized water. The solutions were circulated through the solution compartment of the test cell at a flow rate of $5 \mathrm{~cm}^{3} \mathrm{~s}^{-1}$.

The liquid pressure on the GDE could be varied by means of variation of the height of the solution storage vessel. The height difference between the cell and the solution storage vessel was adjustable in the range 0 to $1 \mathrm{~m}$, equivalent to a pressure from 1.0 to 1.1 bar. The temperature of the solution was kept constant by a heat exchanger near the solution inlet of the test cell.

Hydrogen added to an inert gas stream was fed to the gas compartment of the test cell. The inert gases used were nitrogen, helium and argon. The inert gas flow rate was controlled by a valve and measured by a Fischer \& Porter 02F-1/8" -12.5 flowmeter fitted with a sapphire float. Hydrogen generated at constant current from a $4 \mathrm{M} \mathrm{KOH}$ solution was added to the inert gas stream.

The gas overpressure was applied by a water column fitted to the gas outlet of the test cell. The height of the water column was adjustable in the range 0 to $1 \mathrm{~m}$, equivalent to a pressure from 1.0 to 1.1 bar. The gas temperature was controlled by means of a heat exchanger near the gas inlet of the test cell. A thermostatted vessel that could be filled with water was situated in the gas inlet circuit. By means of this cell the inlet gas could be saturated with water vapour at the cell operating temperature.

Cyclic voltammograms were recorded using a Solartron 1286 electrochemical interface (ECI) controlled by a microcomputer. The potential range of $1 \mathrm{~V}$ between the equilibrium potential of the gas diffusion electrode, $E_{\mathrm{e}}$, and the more positive potential, $E_{\mathrm{t}}=E_{\mathrm{e}}+1 \mathrm{~V}$, was scanned at a rate of $5 \mathrm{mV} \mathrm{s}^{-1}$ in the ECIs stepped sweep mode at a stepping rate of $1 \mathrm{~s}^{-1}$.

Electrochemical impedance spectra were recorded using the ECI and the Solartron 1250 frequency response analyser (FRA). Ohmic drops between the tip of the Luggin capillary and the gas diffusion electrode were calculated using these impedance spectra. Potentials used in this work are referred to $E_{\mathrm{e}}$ and the overpotential $\eta=E-E_{\mathrm{e}}$ was corrected for ohmic drop.

\section{Results}

Diffusion-limited current densities were determined using the mean current density value for the scans in the potential range 0.3 to $0.5 \mathrm{~V}$. The diffusion-limited current density $i_{\mathrm{gd}, 1}$ is calculated as the mean value of the mean values in the positive potential direction and of those in the negative potential direction to account for (pseudo) double layer effects.

Figure 2 shows the influence of the concentration of sulphuric acid, $c_{\mathrm{SA}}$, on the diffusion-limited current density, $i_{\mathrm{gd}, 1}$, at various hydrogen concentrations in the hydrogen/nitrogen mixture, $c_{\text {in }}$, at a constant volumetric flow rate of nitrogen gas, $F_{\mathrm{v}, \mathrm{N}}$, at constant temperature $T$. The data are averaged from multiple

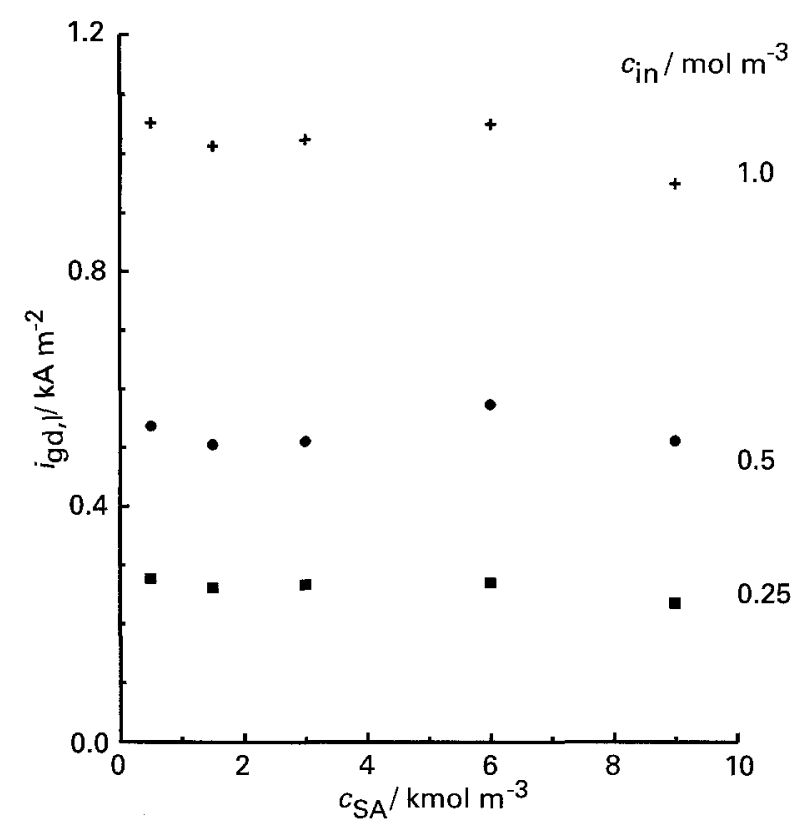

Fig. 2. The diffusion limited current density, $i_{\mathrm{gd}, \mathrm{t}}$, as a function of the sulphuric acid concentration in the solution, $c_{\mathrm{SA}}$, at a temperature of $293 \mathrm{~K}$ and various hydrogen gas inlet concentrations. The volumetric nitrogen flow rate: $5.08 \mathrm{~cm}^{3} \mathrm{~s}^{-1}$.

measurements. Measurements at sulphuric acid concentrations over $9 \mathrm{M}$ are not reliable, since the electrode deactivates due to the products formed from the Perspex of the test cell. The mass transport coefficient $k_{\mathrm{s}}$ was calculated according to [7] using

$$
\begin{aligned}
i_{\mathrm{gd}, 1}= & \frac{n \mathscr{F}}{2 V_{\mathrm{m}} A_{\mathrm{gd}}}\left(\left(F_{\mathrm{v}, \text { in }}+k_{\mathrm{s}} A_{\mathrm{gd}}\right)\right. \\
& \left.-\sqrt{\left(F_{\mathrm{v}, \text { in }}+k_{\mathrm{s}} A_{\mathrm{gd}}\right)^{2}-4 k_{\mathrm{s}} A_{\mathrm{gd}} F_{\mathrm{v}, \text { in }} V_{\mathrm{m}} c_{\mathrm{in}}}\right)
\end{aligned}
$$

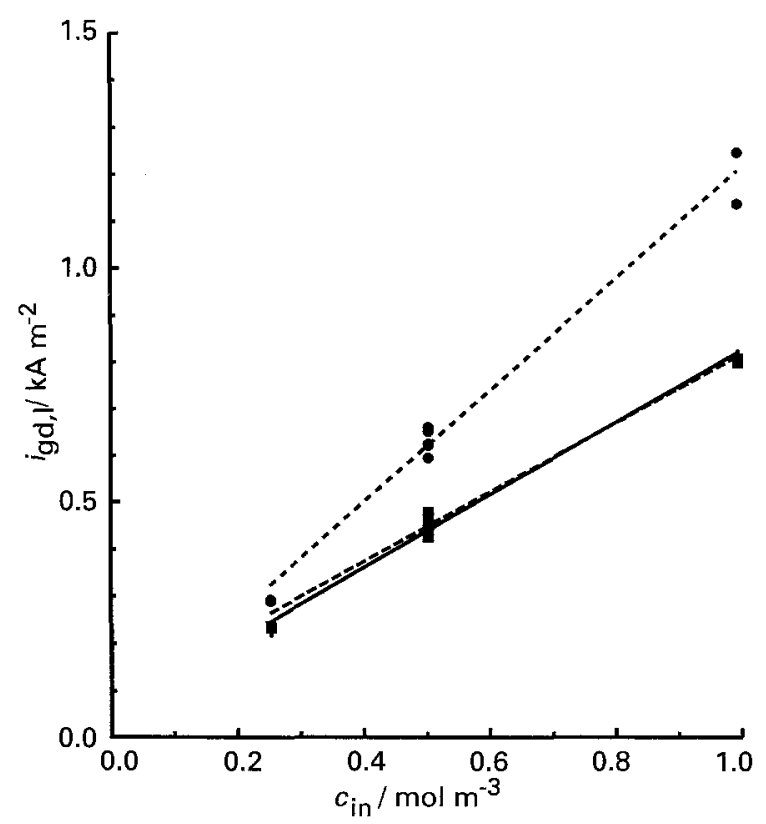

Fig. 3. The diffusion limited current density, $i_{\mathrm{gd}, 1}$, as a function of the gas inlet concentration, $c_{\mathrm{jn}}$, at a temperature of $293 \mathrm{~K}$ and an inert gas flow of $5.08 \mathrm{~cm}^{3} \mathrm{~s}^{-1}$. Inert gases used are (a) $\mathrm{Ar},(\mathbf{O})$ $\mathrm{He},(+) \mathrm{N}_{2}$. 
Table 1. Interdiffusion coefficients from literature for hydrogen in various inert gases, calculated overall mass transport coefficients for $T=293 K$

\begin{tabular}{llr}
\hline Inert gas & $10^{4} \times D_{H_{2}, j} / \mathrm{m}^{2} \mathrm{~s}^{-1}$ & \multicolumn{1}{c}{$k_{s} / \mathrm{ms}^{-1}$} \\
\hline Nitrogen & 0.74 & $7.33 \times 10^{-3}$ \\
Argon & 0.80 & $6.94 \times 10^{-3}$ \\
Helium & 1.40 & $11.68 \times 10^{-3}$ \\
\hline
\end{tabular}

$k_{\mathrm{s}}$ was calculated to be $8.9 \times 10^{-3} \mathrm{~m} \mathrm{~s}^{-1}$ with a standard deviation $\sigma$ of $0.6 \times 10^{-3} \mathrm{~m} \mathrm{~s}^{-1}$ for $0.5,1.5$ and $3 \mathrm{M}$ sulphuric acid. For $6 \mathrm{M}$ and $9 \mathrm{M}$ sulphuric acid, $k_{\mathrm{s}}$ was calculated to be $10.3 \times 10^{-3}$ and $8.0 \times$ $10^{-3} \mathrm{~m} \mathrm{~s}^{-1}$ with standard deviations of $0.7 \times$ $10^{-3} \mathrm{~m} \mathrm{~s}^{-1}$ and $0.5 \times 10^{-3} \mathrm{~m} \mathrm{~s}^{-1}$, respectively.

Figure 3 shows the influence of the hydrogen concentration in the inlet gas, $c_{\mathrm{in}}$, on $i_{\mathrm{gd}, 1}$ at a constant volumetric flow rate of inert gas for $\mathrm{N}_{2}, \mathrm{Ar}$ and $\mathrm{He}$ as inert gases. The calculated mass transport coefficients are tabulated in Table 1.

Figure 4 shows the influence of temperature on the diffusion-limited current density, $i_{\mathrm{gd}, 1}$, at a constant hydrogen production current and at a constant nitrogen gas mass flow rate. As the temperature increases from 293 to $353 \mathrm{~K}, c_{\text {in }}$ decreases and $F_{\mathrm{v}, \text { in }}$ increases. Figure 4 shows measurements for gas saturated with water vapour at $293 \mathrm{~K}$, as well as for gas saturated with water vapour at the operating temperature of the cell.

Figure 5 shows the influence of gas pressure as well as solution pressure on the diffusion-limited current density, $i_{\mathrm{gd}, 1}$, at a constant $T, l_{\mathrm{hp}}$ and nitrogen gas mass flow rate. Since the gas pressure is varied, both $c_{\text {in }}$ and $F_{\mathrm{v}, \text { in }}$ vary.

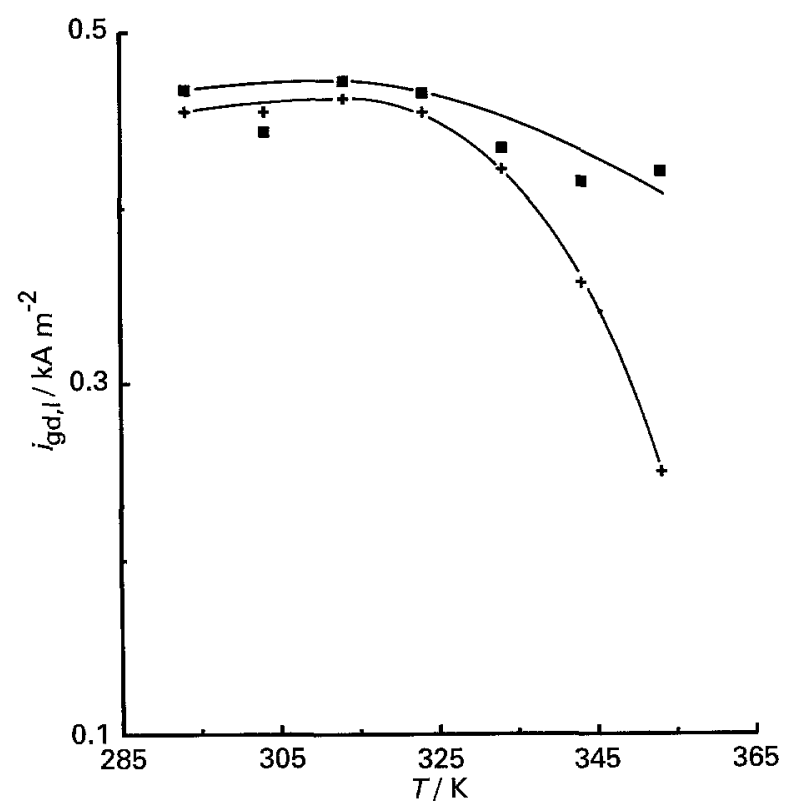

Fig. 4. Measured diffusion limited current densities, $i_{\mathrm{gd}, 1}$, as a function of the cell operating temperature at a nitrogen gas flow rate of $5.08 \mathrm{~cm}^{3} \mathrm{~s}^{-1}$ at $293 \mathrm{~K}$ and at a hydrogen production current $I_{\mathrm{hp}}$ of $0.5 \mathrm{~A}$. The gas fed to the cell was saturated with water at $293 \mathrm{~K}$ (ש) or saturated with water at the cell operating temperature $(+)$.

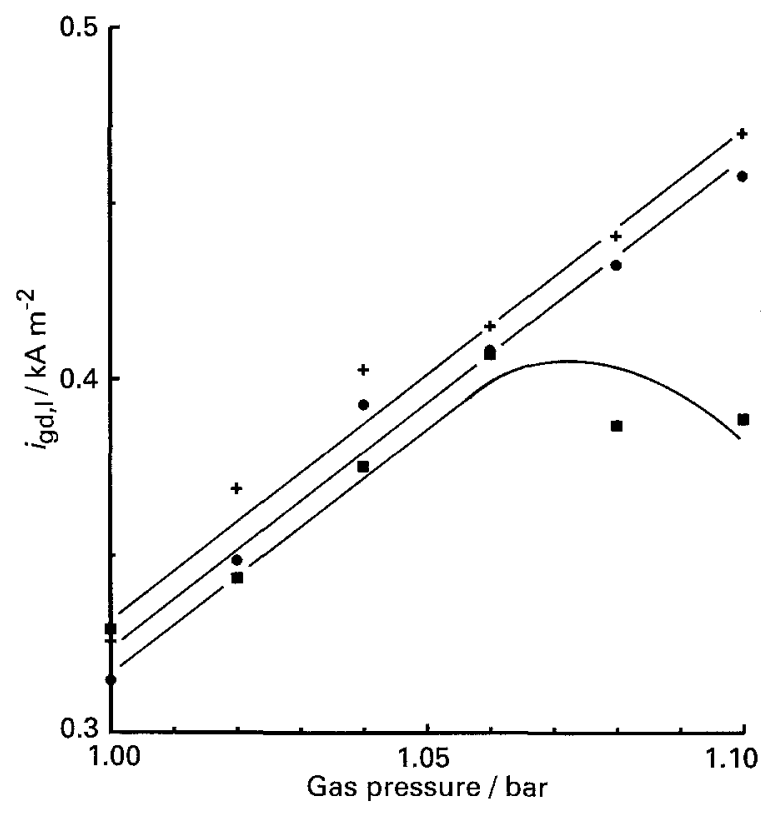

Fig. 5. The diffusion limited current density, $i_{\text {gd }, 1}$, as a function of the gas pressure at a nitrogen gas flow rate of $5.08 \mathrm{~cm}^{3} \mathrm{~s}^{-1}$ at 1.0 bar, a temperature of $293 \mathrm{~K}$, a hydrogen production current of $0.5 \mathrm{~A}$ and a liquid pressure of $1.0(\boldsymbol{\square}), 1.05(\mathbf{O})$ and $1.1(+)$ bar.

\section{Theoretical analysis}

Various models have been proposed to account for the behaviour of gas diffusion electrodes [1-6, 8-10]. An applicable model to explain the behaviour observed includes a porous backing acting as support, current collector and gas transport layer combined with a reaction layer consisting of a network of drowned and gas-filled pores. To estimate the influence of diffusion coefficients on the overall mass coefficient, a simplified model based on, for example, References 4-6 using effectiveness factors for the gas filled macropores and the drowned micropores in the reaction layer is derived below. In this model, three stages of hydrogen transport are combined:

1. transport of hydrogen through the gas-filled macropores of the porous backing.

2. transport of hydrogen gas in the gas-filled macropores of the reaction layer where, simultaneously, dissolution of hydrogen gas in the solution present in the micropores of the reaction layer takes place.

3. transport of dissolved gas in the solution-filled micropores of the reaction layer, where oxidation of dissolved hydrogen on the catalyst sites on the micropore walls occurs simultaneously.

The pore properties in the respective stages are given by their effective length, radius and concentration per unit of geometric electrode surface area $L, r$ and $M$ (Fig. 6).

In a previous paper [7] the overall mass transport coefficient for hydrogen, $k_{\mathrm{s}}$, was defined by

$$
i_{\mathrm{gd}, 1}=2 \mathscr{F} k_{\mathrm{s}} c_{\text {out }}
$$

The hydrogen flux into a single pore of the porous backing, where no reaction occurs, can be approxi- 


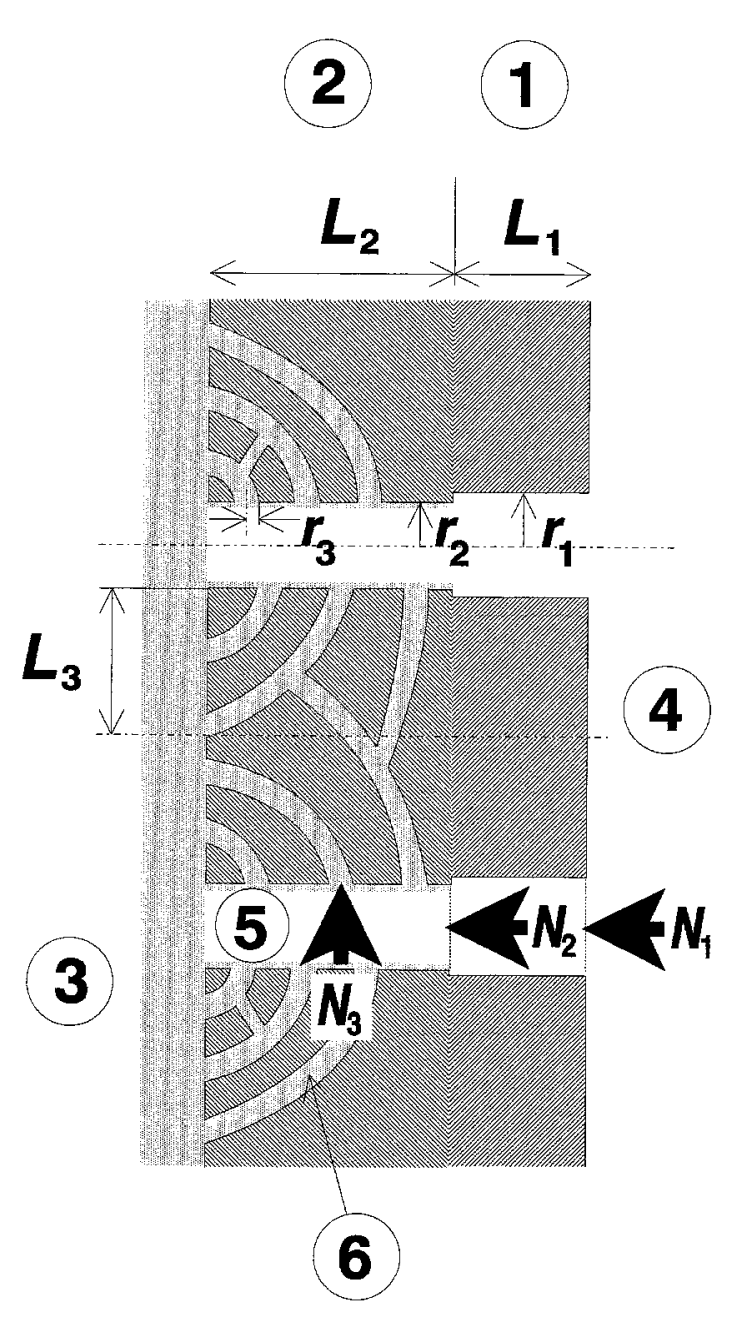

Fig. 6. Schematic illustration of a gas diffusion electrode. (1) Porous backing, (2) reaction layer, (3) solution, (4) gas, (5) macropore and (6) micropore.

mated by

$$
N_{1}=\left(D_{i, j} / L_{1}\right)\left(c_{\text {out }}-c_{1,2}\right) S_{1}
$$

where $c_{1,2}$ is the concentration at the interface of the porous backing and the reaction layer. This concentration is also the concentration of hydrogen at the mouth of the macropores of the reaction layer. In this approximation, the influence of water vapour and pressure effects are neglected. The current density for the hydrogen oxidation expressing the rate of hydrogen transport into the porous backing becomes

$$
i_{\text {gd }, 1}=2 \mathscr{F} N_{1} M_{1}
$$

The flux of hydrogen into the mouth of a gas-filled macropore of the reaction layer can be approximated by (e.g. [14]):

$$
N_{2}=\phi_{2} \tanh \left(\phi_{2}\right)\left(D_{i, j} / L_{2}\right) c_{1,2} S_{2}
$$

where $\phi_{2}$ is the Thiele modulus for the cylindrical macropores of the reaction layer, defined as

$$
\phi_{2}=L_{2}\left(2 k_{2} / r_{2} D_{i, j}\right)^{1 / 2}
$$

The current density equivalent to the flux into these pores is

$$
i_{\mathrm{gd}, 1}=2 \mathscr{\mathscr { F }} N_{2} M_{2}
$$

A combination of Equations 2, 3, 4, 5 and 7 gives an expression for the overall mass transport coefficient $k_{\mathrm{s}}$ :

$$
k_{\mathrm{s}}=\frac{\left(D_{i, j} / L_{2}\right) M_{1} S_{2} \phi_{2} \tanh \phi_{2}}{\left(M_{1} / M_{2}\right)+\left(S_{2} L_{1} / S_{1} L_{2}\right) \phi_{2} \tanh \phi_{2}}
$$

To evaluate the transport rate constant for hydrogen transport into the micropores of the reaction layer, $k_{2}$, as a function of the rate constant of reaction on the surface of the catalyst, $k_{3}$, the hydrogen concentration in the gas phase of the macropore is assumed to be in equilibrium with the hydrogen concentration in the solution of the micropore at the gasliquid interface:

$$
c_{2,3, \mathrm{~L}}=H c_{2,3, \mathrm{G}}
$$

Assuming that radial diffusion is not rate-determining, $c_{2,3, \mathrm{G}}$ can be set equal to $c_{2}$.

The reaction at the surface of the micropore is assumed to be first order with respect to the hydrogen concentration in the solution, $c_{3}$. Again, radial diffusion is assumed not to be rate-determining. The reaction rate constant, $k_{3}$, is a function of the catalyst surface concentration and the potential applied. The surface rate of reaction at the surface of the micropore is defined as

$$
i_{3} /(2 \mathscr{F})=k_{3} c_{3}
$$

For a single cylindrical micropore, the flux into this pore can be calculated to be

$$
N_{3}=\phi_{3} \tanh \phi_{3}\left(D_{1} / L_{3}\right) S_{3} c_{2,3, \mathrm{~L}}
$$

where $\phi_{3}$ is the Thiele modulus for a cylindrical micropore in the reaction layer, defined as:

$$
\phi_{3}=L_{3}\left(2 k_{3} / r_{3} D_{1}\right)^{1 / 2}
$$

The micropore density on the macropore surface can be estimated using

$$
M_{3}^{\prime}=M_{3} /\left(2 \pi r_{2} L_{2} M_{2}\right)
$$

Combining Equations 9, 11 and 13, the rate constant for transport of hydrogen gas into the macropores wall of the reaction layer becomes

$$
k_{2}=\phi_{3} \tanh \phi_{3}\left(D_{1} / L_{3}\right) S_{3} M_{3}^{\prime} H
$$

Equations 6, 8, 12 and 14 can be used to evaluate the dependence of $k_{\mathrm{s}}$ on $D_{i, j}$ and $D_{1}$.

If $S_{1} M_{1} / L_{1} \gg S_{2} M_{2} / L_{2}$, there is no dependence on $\phi_{2}$. Then $k_{\mathrm{s}}$ can be shown to be

$$
k_{\mathrm{s}}=S_{1} M_{1} D_{i j} / L_{1}
$$

This implies that the mass transport of hydrogen is completely determined by the porous backing; the rate of hydrogen transport becomes independent of the process occurring in the reaction layer. This result is consistent with the result derived by Kimble et al. for limiting gas diffusion through a membrane [11-13].

For the cases where $S_{1} M_{1} / L_{1} \ll S_{2} M_{2} / L_{2}$, the expression for $k_{\mathrm{s}}$ becomes dependent on $\phi_{2}$. If diffusion of gas through the macropores in the reaction 
layer is the faster process $\left(\phi_{2}<0.2\right)$, tanh $\phi_{2}$ becomes approximately equal to $\phi_{2}$ and $k_{\mathrm{s}}$ can be described by

$$
k_{\mathrm{s}}=2 k_{2} L_{2} M_{2} S_{2} / r_{2}
$$

In this case, $k_{\mathrm{s}}$ becomes independent of the diffusion coefficient in the gas phase, $D_{i, j}$. This result is consistent with the expressions for the diffusion limited current density as derived by Stonehart et al. [15] and Cutlip [4].

If diffusion of gas through the macropores in the reaction layer is the slowest process $\left(\phi_{2}>2.7\right)$, tanh $\phi_{2}$ becomes approximately equal to 1 and $k_{\mathrm{s}}$ can be described by

$$
k_{\mathrm{s}}=M_{2} S_{2}\left(2 k_{2} D_{i, j} / r_{2}\right)^{1 / 2}
$$

This result is analogous to that one found for catalytic surface reactions in porous catalyst particles (e.g. [14]) and is consistent with the expression derived by Cutlip [4].

Expressions for $k_{2}$ depending on the value of $\phi_{3}$ can be derived for strong diffusion resistance in the micropores of the reaction layer $\left(\phi_{3}>2.7, \tanh \phi_{3} \approx 1\right.$, Equation 18) and for a slow surface reaction ( $\phi_{3}<0.2, \tanh \phi_{3} \approx \phi_{3}$, Equation 19). It was found that $k_{2}$ is, respectively,

$$
k_{2}=S_{3} M_{3}^{\prime} H\left(2 k_{3} D_{1} / r_{3}\right)^{1 / 2}
$$

and

$$
k_{2}=2 k_{3} L_{3} S_{3} M_{3}^{\prime} H / r_{3}
$$

So, depending on the value of $\phi_{3}$, the dependence of $k_{\mathrm{s}}$ on $D_{1}^{\mathrm{n}}$ with a value of $\mathrm{n}$ between 0 and 0.5 will be observed.

\section{Discussion}

As can be seen from Fig. 2, there is very little influence of the sulphuric acid concentration on the diffusion-limited current density for hydrogen oxidation in the GDE. The diffusion coefficient for dissolved hydrogen, $D_{1}$, decreases from approximately $0.35 \times 10^{-9} \mathrm{~m}^{2} \mathrm{~s}^{-1}$ to $0.20 \times 10^{-9} \mathrm{~m}^{2} \mathrm{~s}^{-1}$ when $c_{\mathrm{SA}}$ increases from 0.5 to $9 \mathrm{kmol} \mathrm{m}^{-3}$ [16]. The solubility of hydrogen in sulphuric acid, as quantified by the Bunsen-coefficient $\alpha$, also decreases by a factor of approximately 2.5 for the same increase in $c_{\mathrm{SA}}$ [17]. This means that $H$ decreases by a factor 2.5 with increase in $c_{\mathrm{SA}}$ from 0.5 to $9 \mathrm{kmol} \mathrm{m}^{-3}$. These changes should result in a large decrease in the diffusion limited current density if mass transport of hydrogen in the liquid layer influences the overall process. We can therefore rule out this process as rate determining.

Table 1 shows the influence of the inert gas on the overall mass transport coefficient $k_{\mathrm{s}}$ and the interdiffusion coefficients for hydrogen in various inert gases [18]. The mass transport coefficient is not proportional to $d_{i, j}$ but almost proportional to $D_{i, j}^{0.8}$. The value of 0.8 was obtained by least squares approximation from $k_{\mathrm{s}}=k_{\mathrm{s}, 0} D_{i, j}^{\mathrm{n}}$. This indicates that diffusion of hydrogen through the pores of the porous backing of the electrode combined with diffu- sion in the gas phase of the macropores of the reaction layer of the GDE determines the limiting current of hydrogen oxidation. The diffusion of hydrogen gas in both layers contributes to the overall diffusion resistance. Since only a small influence of $H$ was observed, it is concluded that the major resistance for hydrogen transport is located in the porous backing.

The dependence of the diffusion limited current density, $i_{\mathrm{gd}, 1}$, on the operating temperature, $T$, is shown in Fig. 4 for both experiments with gas saturated with water vapour at $293 \mathrm{~K}$ as well as for those with gas saturated with water vapour at the cell operating temperature. The difference in $i_{\mathrm{gd}, 1}$ is caused by a difference in water vapour content of the inlet gas; in particular at temperatures over approximately $330 \mathrm{~K}$. If the gas inside the pores of the gas diffusion electrode were in equilibrium with the solution inside those pores, the gas inside the pores would have approximately the same composition for both types of measurements resulting in the same diffusion-limited current density. However, a large difference has been found. It is therefore concluded that the gas inside the pores is not in equilibrium with the solution at higher temperatures.

From the data plotted in Fig. $4, k_{\mathrm{s}}$ values have been calculated using Equation 1 , where $V_{\mathrm{m}}, c_{\text {in }}$ and $F_{\mathrm{v}, \text { in }}$ were corrected for temperature increase using the ideal gas law. The data from the experiments with gas saturated with water vapour at the cell operating temperature were also corrected for the influence of water vapour on the composition of the gas using partial vapour pressure data from [19]. The water vapour correction at $293 \mathrm{~K}$ was neglected. These corrected $k_{\mathrm{s}}$ values are shown in Fig. 7. From this figure it follows that the interdiffusion coefficient for hydrogen, $D_{i, j}$, does not solely determine the behaviour of $k_{\mathrm{s}}$ at elevated temperatures, since $D_{i, j}$ increases continuously with increasing temperature [18] and with increasing water vapour content of the gas [20]. $k_{\mathrm{s}}$, however, decreases at temperatures over approximately $325 \mathrm{~K}$. Since a maximum is observed at practically the same temperature for gas saturated with water at $293 \mathrm{~K}$, as well as for gas saturated with water at the cell operating temperature, the decrease cannot be caused by the evaporation of water inside the pores of the gas diffusion electrode [7]. Possibly, the decrease in $k_{\mathrm{s}}$ at temperatures higher than $325 \mathrm{~K}$ is caused by changes in the wetting behaviour of the gas diffusion electrode. Due to lowering of the surface tension of the solution, the electrode becomes more flooded.

From Fig. 5, it follows that there is a steep increase in diffusion limited current density with increasing gas pressure. This increase cannot be explained from an increase in the hydrogen concentration of the gas fed. An increase of approximately $7 \%$ in $i_{\mathrm{gd}, 1}$ is predicted using the ideal gas law if the gas pressure is increased from 1.0 to $1.1 \mathrm{bar}$, however, the measured increase in $i_{\mathrm{gd}, 1}$ amounts to approximately $44 \%$. The experimental increase may be explained 


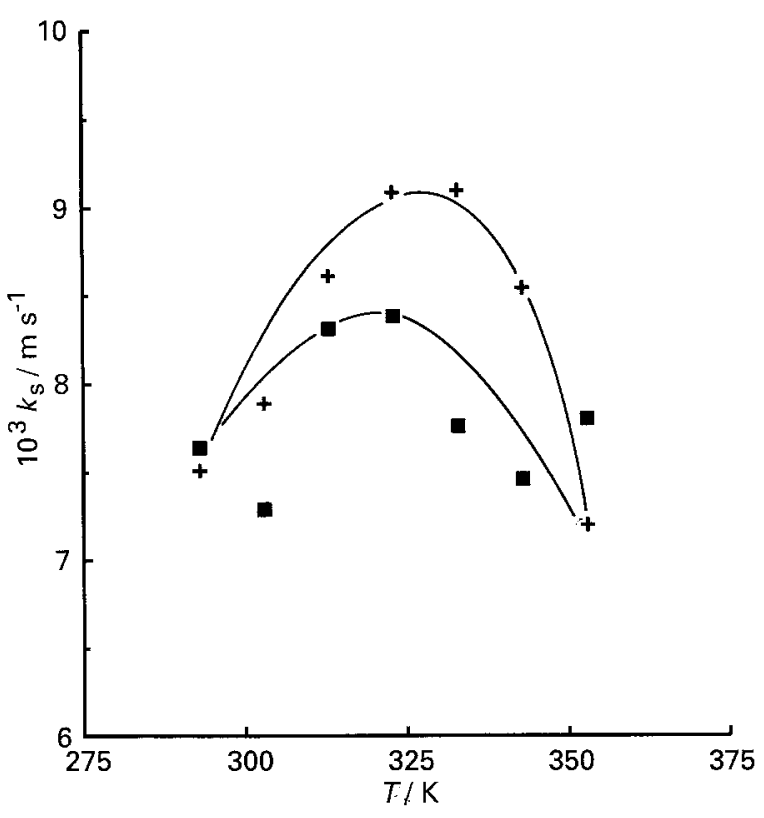

Fig. 7. The overall mass transport coefficient $k_{\mathrm{s}}$ calculated from the data in Fig. 5 as a function of the cell operating temperature $T$. The gas fed to the cell was saturated with water at $293 \mathrm{~K}(\boldsymbol{\square})$ or saturated with water at the cell operating temperature $(+)$.

by a reduction of solution blockage of narrow pores of the electrode at increasing gas pressure, resulting in higher utilization of the electrode [10]. The pressure difference between the gas side pressure and the liquid side pressure has to be maintained within certain limits to obtain good utilization of the GDE as may be deduced from Fig. 5 .

\section{Acknowledgement}

This work was supported by Hoogovens IJmuiden, The Netherlands.

\section{References}

[1] I. Roušar, K. Micha and A. Kimla, 'Electrochemical Engineering', Chemical Engineering Monographs $21 \mathrm{~B}$, Elsevier, Amsterdam (1986).

[2] M. W. Breiter, 'Electrochemical Processes in Fuel Cells', Anorganische und allgemeine Chemie in Einzeldarstellungen $I X$, Springer Verlag, Berlin (1969).

[3] D. M. Bernardi and M. W. Verbrugge, AIChE J. 37 (1991) 1151

[4] M. B. Cutlip, Electrochim. Acta 20 (1975) 767.

[5] S. C. Yang, M. B. Cutlip and P. Stonehart, ibid. 34 (1989) 703.

[6] Idem, ibid. 36 (1991) 547.

[7] J. J. T. T. Vermeijlen and L. J. J. Janssen, J. Appl. Electrochem. 23 (1993) 26.

[8] L. G. Austin and Satish Almaula, J. Electrochem. Soc. 114 (1967) 927.

[9] K.-Y. Chan, G. S. Efthymiou and J. F. Cocchetto, Electrochim. Acta 32 (1987) 1227.

[10] W. Jenseit, 'Untersuchungen zur morphologischen Charakterisierung von Gasdiffusionselektroden', Thesis, Technischen Hochschule Darmstadt, Darmstadt (1990).

[11] M. C. Kimble, R. E. White, Y.-M. Tsou and R. Neal Beaver, J. Electrochem. Soc. 127 (1990) 2510.

[12] D. Fan, R. E. White and N. Gruberger, J. Appl. Electrochem. 22 (1992) 770.

[13] Y.-M. Tsou, M. C. Kimble and R. E. White, J. Electrochem. Soc. 139 (1992) 1913.

[14] O. Levenspiel, 'Chemical Reaction Engineering', John Wiley \& Sons, New York (1972).

[15] P. Stonehart and P. N. Ross, Electrochim. Acta 21 (1976) 441.

[16] 'International Critical Tables of Numerical Data, Physics, Chemistry and Technology' Vol. 5, (edited by E. W. Washburn) McGraw-Hill, New York (1929).

[17] 'Solubility Data Series', Vol. 5/6, (edited by C. L. Young) IUPAC/Pergamon Press, Frankfurt (1981).

[18] Landolt-Börnstein, 'Zahlenwerten und Funktionen aus Physik, Chemie, Astronomie, Geophysik, Technik', 6: auflage, 2. band, 5. teil, bandteil $a$, Springer Verlag, Berlin (1969).

[19] 'International Critical Tables of Numerical Data, Physics, Chemistry and Technology', Vol. 3, (edited by E. W. Washburn), McGraw-Hill, New York (1929)

[20] J. O. Hirschfelder, C. F. Curtiss and R. B. Bird, 'Molecular Theory of Gases and Liquids', (4th printing), John Wiley \& Sons, New York (1967). 